\title{
The Origins of Generalized and Political Trust among Immigrant Minorities and the Majority Population in the Netherlands
}

\author{
De Vroome, T., Hooghe, M., Marien, S.
}

NOTE: post-print version, April 17, 2013

This article may not exactly replicate the final version published in the journal.

It is not the copy of record.

The definitive version is available online:

De Vroome, T., Hooghe, M., Marien, S. (2013).

The Origins of Generalized and Political Trust among Immigrant Minorities and the

Majority Population in the Netherlands.

European Sociological Review, 29(6):1336-1350.

http://dx.doi.org/10.1093/esr/jet018 


\begin{abstract}
In this study, we investigate whether differences in generalized and political trust levels between immigrants and natives are related to immigrants' relatively disadvantaged socioeconomic positions in society. We compare trust levels for native Dutch respondents and Turkish and Moroccan minorities, based on the NELLS population survey (2009, $n=4,222)$. The results demonstrate that there are significant differences between immigrants and natives in the levels of generalized and political trust. Regarding trust in political institutions, however, the initially observed differences could almost fully be attributed to differences in economic position and social resources. We conclude that the economic and social integration of immigrants in society is most clearly associated with native-immigrant differences in political trust, but objective living conditions are also related to immigrants' generalized trust. Therefore, policies aiming to improve immigrants' economic and social integration in society will generally be conducive to generalized and political trust levels.
\end{abstract}

Key words: Generalized trust, Political trust, Immigration, Immigrant minorities, Integration 
The Origins of Generalized and Political Trust among Immigrant Minorities and the Majority Population in the Netherlands

\section{Introduction}

Research has shown in a convincing manner that trusting societies perform better and are able to establish higher levels of quality of life levels for their inhabitants (Putnam 1993, 2000). Trust reduces transaction costs and enables collective action. This is not just the case with generalized trust: societies with higher levels of political trust levels are characterised by more effective and legitimate political systems (Easton 1965; Marien and Hooghe 2011). In recent decades, however, diversity has transformed traditional (political) communities and it is assumed that this also has an effect on levels of generalized and political trust. As a result, the relationship between increasing ethnic diversity and feelings of trust has come under intense scrutiny in recent years (Delhey and Newton, 2005; Hooghe, 2007; Putnam, 2007). In his well-cited article "E pluribus Unum", Putnam (2007) argues that in the short run ethnic diversity is likely to erode trust levels in society. Diversity is also argued to affect political trust levels as the heterogeneity of the political community increases and shared identities and values come under pressure (McLaren 2012). While initially this research line mainly focused on the question what effect ethnic diversity could have on the trust levels of the original population of a country, more recently, research attention has shifted to the question what determines the levels of trust among minority communities themselves (Wilkes, 2011).

It has been argued that generalized trust and trust in political institutions can be seen as aspects of immigrants' psychological integration, which is defined as feelings of identification, belonging and commitment in the host society (Esser, 2003). Previous research has shown substantial differences in the trust levels of the immigrant population and the majority population. Theories on 'stages' or 'domains' of immigrant integration suggest that immigrants' psychological integration in society crucially depends on their economic and social integration (Esser, 2003). As a result, this model predicts that trust levels of immigrant minority populations should adjust to those of the host society, to the extent that these groups advance in terms of economic and social integration.

The question whether immigrant minorities acculturate to the trust level of host societies is thus very relevant from the perspective of societal and political debates on immigrant integration. In recent years, quite some politicians and other social actors have 
wondered whether the integration of immigrant minorities in Western Europe can be regarded as successful. To some extent trust measurements offer us an indirect answer to that question, as it can be assumed that trust amounts to a general assessment of the society or the political system one resides in, related to feelings of belonging and commitment, which is a crucial prerequisite for cohesion and economic development in society (Alesina and La Ferrara, 2002; Newton, 1997). If we would find that immigrant minorities have persistent lower levels of trust than the original population, this could imply, either that these groups have not really integrated into their new society, or that they indeed have good reasons to be distrustful, as suggested in some of the research on different trust levels of black and white US citizens (Michelson, 2003; Smith, 2010).

In this study, we investigate the origins of trust, by comparing two distinct forms of trust. In particular, we compare natives and immigrant minorities with regard to generalized trust, i.e. the feeling that most people can be trusted, and with regard to trust in political institutions. In order to investigate the determinants of both forms of trust, we rely on an analysis of the first wave of the Netherlands Longitudinal Lifecourse Study (NELLS), which was conducted in 2009 and included an oversampling of members of the Turkish and Moroccan communities in the Netherlands (De Graaf et al., 2010a). In this article we briefly review the literature on determinants of trust. Subsequently we present the data and methods before going into the results of this study. In the discussion we ascertain what these findings tell us about the determinants of generalized trust and trust in political institutions.

\section{Theory and Hypotheses}

\section{The relation between integration and trust}

The basic distribution of high and low trust societies has not changed all that much during the past decades (Nannestad, 2008; Marien, 2011). In most of the research it is therefore assumed that the reason for this stability lies in the fact that feelings of trust are internalized early on in life, and remain relatively stable thereafter. The persistence theory, which is most clearly formulated in the work of Uslaner, departs from a specific conceptualization of trust which is cultural or moralistic rather than strategic or rational (Nannestad, 2008; Uslaner, 2002). This trust concept implies that trust is a general outlook on human nature, which is not based on actual experience of others' trustworthy behaviour, but on early socialization experiences (Uslaner, 2002). The persistence theory would therefore predict that immigrant minorities are 
and will remain distinct from the majority population with regard to their level of generalized trust (Uslaner, 2008).

Uslaner (2008), e.g., has shown that US citizens from Scandinavian descent are still characterized by the generalized trust levels of their country of origin, even if their ancestors already migrated to the United States some generations ago. Dinesen and Hooghe (2010) have also shown that trust levels of first and to a lesser extent second generation immigrants are lower than trust levels of the general population. This analysis relies on the results of the European Social Survey, but the authors acknowledge that sampling of immigrant minorities is not necessarily uniform or equally successful across European societies.

Other authors claim more strongly that trust is a reflection of actual experiences and thus is open to lifelong learning and adjustment (Delhey and Newton, 2005; Nannestad, 2008). Especially regarding trust in political institutions, it has been demonstrated that trust reacts strongly to stimuli provided by the environment (Zmerli and Hooghe, 2011). Political trust has for instance been shown to be strongly influenced by the perceived performance of political institutions and actors (Kumlin and Rothstein, 2010; Rothstein and Stolle, 2003). Also regarding generalized trust, however, it has been argued that trust depends on learning experiences and perceived trustworthiness in past interactions (Alesina and La Ferrara, 2002; Nannestad, 2008).

It can be assumed therefore that when the social and political environment are the same for natives and immigrant minorities, we can expect that immigrant minorities adapt to the trust levels that are prevalent within the host society (Aleksynska, 2011; Dinesen and Hooghe, 2010). The notion of integration and learning prompts the question what kind of learning experiences and social integration matter. In this regard, trust has also been described as a characteristic for the 'winners in society' (Newton, 1997). People who have been able to attain good socio-economic positions are more likely to have the sense that they are generally treated fairly by others (Alesina and La Ferrara, 2002). Conversely, if an individual has been hurt in past interactions, feels thwarted in his or her attempts to secure a good socio-economic position through education and climbing the occupational ladder, he or she will trust less (Alesina and La Ferrara, 2002). Because immigrant minorities, both first and second generation, generally hold less favourable socio-economic positions, this may be associated with a lower level of trust among these groups.

In other words, minorities' feelings of trust and belonging in the host society depend on their economic and social integration in society, as has also been suggested in sociological theories on immigrant integration (Esser, 2003). Indeed, the crucial question in this study is to 
what extent factors associated with immigrant minorities' socio-economic integration in society are related to trust levels, and whether these socio-economic disadvantages can help explain the differences in trust levels between natives and minorities.

The distinction between generalized trust and trust in political institutions is important, because the research on trust in political institutions generally departs from a rational or 'experiential' conceptualization of trust, while claims in the literature suggest that generalized trust may also follow a logic of cultural persistence (Dinesen, 2012; Uslaner, 2002). Thus while generalized trust is often thought to be affected by (cultural or normative) origin effects, political trust is thought to be dependent on conditions in the host society (destination effects). Comparing both attitudes should allow us to arrive at a better understanding of the extent to which immigrants' socio-economic integration in society is related to their levels of generalized trust and trust in political institutions. Therefore we expect that political trust will be more strongly associated with immigrants' socio-economic integration in society. This leads to the following two hypotheses:

H1. The level of generalized trust among immigrant minorities will be distinct from the trust level of native Dutch.

H2. Taking socio-economic disadvantages into account, the level of trust in political institutions among immigrant minorities will not be significantly different from the level among native Dutch.

We can expect that the first generation immigrant minorities will be less integrated than the second generation. Therefore, we expect the first generation to have lower trust levels than natives, while second generation immigrant minorities are expected to occupy an intermediate position.

\section{Civic participation and trust}

The notion that trust is acquired through social interaction and integration has also given rise to the idea that trust is formed through civic participation, and social interaction more generally. The most well-known example is the presumed importance of membership of voluntary organizations (Putnam, 2000). The underlying assumption is that learning to trust others in one's own social circle will create a spillover effect of trusting others more generally in different contexts (Nannestad, 2008). While much research has explicitly focused on 
voluntary organizations, the argument that trusting in general is learned through practice with trusting known others may as well apply to other social contexts. A difference in trust between natives and immigrant minorities may therefore be partially explained by lower civic participation and less extensive social networks of immigrant minorities.

H3. The differences in trust between natives and minorities can be partially explained by civic participation.

\section{Neighbourhood characteristics and trust}

An important debate in the recent literature is whether neighbourhood characteristics, most notably ethnic diversity, will affect trust (Gijsberts, Van der Meer and Dagevos, 2012; Lancee and Dronkers, 2011; Putnam, 2007; Savelkoul, Gesthuizen and Scheepers, 2011). The argument put forth by Putnam as the 'constrict theory' can be seen as an adaptation of homogeneity theory, meaning that it should be more difficult to trust others who are more 'unlike' yourself (Gijsberts, et al., 2012). People who live in a more ethnically diverse neighbourhood will have lower levels of trust, as a result of being surrounded by others to which they feel a relatively large social distance. Another possibly important neighbourhood characteristic is neighbourhood disadvantage. The idea that people in disadvantaged neighbourhoods will be less trusting follows the logic of the success and well-being argument, which can be applied at the group level as well as the individual level (Alesina and La Ferrara, 2002). Because immigrant minorities more often reside in ethnically diverse and economically disadvantaged neighbourhoods, this may partially explain lower trust levels among immigrant minorities.

H4. The differences in trust between natives and minorities can be partially explained by neighbourhood disadvantage and neighbourhood ethnic diversity.

\section{Political orientation and trust in political institutions}

The notions of success and well-being, civic and social participation, and neighbourhood diversity and disadvantage are relevant for both generalized trust and trust in political institutions. Researchers have shown that especially civic participation and social capital positively affect the political trust of immigrant minorities (Fennema and Tillie, 1999; Fennema and Tillie, 2001). It can also be expected, however, that trust in political institutions is affected by distinct political factors. Trust in political institutions is closely related to 
political participation and being interested in politics, as evidenced for instance by a local study among ethnic minorities in Amsterdam (Fennema and Tillie, 1999). Moreover, it is likely that an individual's political trust rises when parties and politicians that appear to share his or her ideals come into power. Differences in political trust between natives and immigrant minorities may therefore be related to differences in political attitudes.

H5. The differences in trust between natives and immigrant minorities can be partially explained by different political attitudes.

\section{Minority-specific determinants of trust}

Lastly, we investigate determinants of trust that are specific to the experience of immigrant minorities. In line with the success and well-being perspective, researchers have noted that members of groups who have a (perceived) history of being treated unfairly will trust less, as in the case of discrimination against minority groups (Alesina and La Ferrara, 2002; Smith, 2010). Also, at the individual level, it can be expected that perceived discrimination will negatively affect the trust of minorities.

H6. Perceived discrimination will be negatively related to immigrant minorities' trust levels.

Furthermore, the homogeneity theory suggests that it is easier to trust others who are perceived to more closely resemble oneself (Alesina and La Ferrara, 2002; Gijsberts, et al., 2012). In the case of immigrant minorities, this leads to the expectation that trust will be higher among those who perceive less social distance towards natives, and who self-identify more with the host country. We also explore the effects of language proficiency, years since migration and nationality in this regard.

\section{Data and Methods}

\section{Data}

For collecting the NELLS data, a random sample of 35 municipalities was selected, stratified by region and degree of urbanization. The four largest cities in the Netherlands were included because of the large proportions of ethnic minorities in these cities. Second, respondents were randomly selected from the population registry based on their age (14 to 45 years), country of birth and parents' country of birth (De Graaf et al., 2010b). 
Minority status was defined according to the official definition of the Dutch Central Bureau of Statistics. First generation Moroccan and Turkish minorities are those individuals who were born in Morocco or Turkey. Second generation Moroccan and Turkish minorities are defined as those individuals of whom one or both parents are born in Morocco or Turkey, but who are themselves born in the Netherlands (De Graaf et al., 2010b).

The survey was administered in Dutch, and both face-to-face interviews and a selfadministered drop-off questionnaire were used. The overall response rate was 52 percent, which is average for this type of survey in the Netherlands (De Graaf et al., 2010b). It should be noted however that response rates were somewhat lower for Moroccan minorities $(46 \%)$ and Turkish minorities (50\%) than for the native Dutch (56\%). The reason is that minority respondents were more difficult to reach and less willing to participate than natives, but minorities could also more often not participate because of language problems (De Graaf et al., 2010b). It has to be acknowledged that this effectively limits the sample to those ethnic minorities that have a sufficient knowledge of Dutch to participate in the survey. The consequence is that our study is not fully representative for the minority population in the Netherlands. Nevertheless it has to be noted that we do not know about any other population survey in Western Europe with such a broad sample of immigrant group respondents.

We excluded the small portion of respondents in the sample (about $7.5 \%$ ) that did not fill out the self-administered part of the survey, because this part contains key items for the analysis. Because only few respondents had missing values on the variables of interest (i.e. about $4 \%$ ), they were also deleted from the sample. All in all, this study includes 4,222 respondents, of which 2,381 are native Dutch, 929 are Moroccan minorities, and 912 are Turkish minorities.

\section{Dependent variables}

Generalized trust was measured with the following statements, to which respondents could answer on a five-point scale: 'You can't be too careful in dealing with people', 'If you trust too easily, people will take advantage of you', and 'You will often be cheated when you help others'. Analysis showed that the items form a coherent scale (Cronbach's Alpha =.71). The items are very similar to other multiple-item measures of generalized trust used in previous research (Dinesen, 2011; Reeskens and Hooghe, 2008). Trust in political institutions was measured with the question: 'Could you indicate how much trust you have in the following institutions: a. politics, b. the government, c. the European Union, and d. the police and justice 
department?', to which respondents could answer on a four-point scale. Analysis showed that these items also form a coherent scale (Cronbach's Alpha $=.83$ ).

\section{Independent variables}

We distinguish five groups of respondents; the native majority, first and second generation Moroccan minorities, and first and second generation Turkish minorities. The measure of minority status is based on respondents' self-reported country of birth and parents' country of birth. About one third of the minority respondents in the sample belong to the second generation, corresponding to the population in the age range of 14 to 45 .

To measure socio-economic status, we focus on education, employment status and financial difficulties. Education is measured on a six-point scale, ranging from no education to higher tertiary education. Because a substantial portion of first generation minorities have pursued education in their country of origin, we also include a measure indicating whether one is educated abroad.

Our measure of respondents' main activity (labour market status) consists of four categories; employed, unemployed, non-active (including, for instance, stay-at-home parents and permanently disabled), and students. For occupational status, we use the international socioeconomic index of occupational status (ISEI)' (Ganzeboom et al., 1992). Unemployed, non-active and student respondents were given the mean score of the employed respondents. ${ }^{1}$ We further include a measure indicating whether employed respondents have a supervising position. To assess financial difficulties, respondents were asked 'Have you, in the past three months, had to deal with the following: a. not being able to replace broken equipment, $b$. having to borrow money for essential expenses, c. falling behind on regular expenses, d. being visited by a bailiff, e. having difficulty making ends meet'. The 'financial problems'-scale was obtained by summing the five items, which form a coherent scale (Cronbach's Alpha $=.73)$.

Furthermore, we use several variables to measure civic and social participation. We account for associational activity by distinguishing members and volunteers from those respondents who have no associational memberships. Six questions were asked on respondents' social resources. This scale was balanced, with three positive items, such as 'there are enough people I can rely on in difficult times', and three 'negative' items, such as 'I often feel abandoned'. Factor analysis indicates that these items constitute two distinct factors. We thus constructed two variables for perceived social support; perceived integration - based on the positive social support items (Cronbach's alpha $=.81$ ), and perceived isolation 
- based on the negative social support items (Cronbach's alpha $=.80$ ). We also include a variable indicating whether one has 'outgroup' friends. The variable perceived collective efficacy in the neighbourhood is based on five items that form a reliable scale (Cronbach's Alpha $=.83$ ). These items strongly resemble those suggested by Sampson et al., (1997), who define collective efficacy as 'social cohesion among neighbours and their willingness to intervene on behalf of the common good' (p. 918). The items are: 'people in this neighbourhood would take action if youths cause disturbance', 'people in this neighbourhood usually greet each other', 'people in this neighbourhood generally get along well', 'people in this neighbourhood are willing to help each other', and 'many people in this neighbourhood know each other'.

We use three political orientation variables. Left-right orientation is measured by asking respondents to place themselves on a scale ranging from ' 0 ' (left) to '10', (right). The variable for interest in politics ranges from ' 0 ' (not at all interested), through ' 1 ' (reasonably interested), to ' 2 ' (very interested). We also include a variable indicating whether the respondent had a preference for one of the parties that were in government in 2009, when the survey was held (a coalition of CDA (centre right), PvdA (centre left) and ChristenUnie (centre left)).

We include several variables that are specifically relevant for minorities. We use a measure of ethnic discrimination; based on questions asking whether respondents ever felt discriminated against in six different situations, such as with job applications or in nightlife. We take the average of the six items, resulting in a reliable scale (Cronbach's Alpha $=.81)^{2}$ We also include host country identification, based on three items such as: 'I strongly identify with the Netherlands'. We take the average of these items, resulting in a reliable scale (Cronbach's Alpha =.86). We further include measures of Dutch language proficiency (based on four items asking whether respondents have difficulty in understanding, speaking, reading and writing in Dutch, which form a highly reliable scale (Cronbach's Alpha $=.96)$ ), how many years respondents are living in the Netherlands, and of whether respondents have the Dutch nationality. ${ }^{3}$

The data also allow us to include neighbourhood characteristics. Respondents are nested within neighbourhoods, based on their six digit postcode (De Graaf et al., 2010b). We include a measure of the proportion of non-Western minorities in the neighbourhood, and the average income (in 100 Euros/person/month) in the neighbourhood. Lastly, we include the demographic control variables age, gender, and family status, because they may affect trust levels (Alesina and La Ferrara, 2002). Table 1 shows the descriptive statistics for natives as 
well as the minority groups. A table of the bivariate correlations is included in the online appendix (Table A.1).

- Table 1 about here -

\section{Analyses}

We first test the measurement invariance of the dependent variables before we assess differences in trust levels between natives and immigrants. Because the respondents are nested within neighbourhoods and we include neighbourhood level predictors, we use multilevel modelling with the 'MIXED' module in SPSS version 19.0 for the main analyses. We use random intercept multilevel models (with restricted maximum likelihood estimation), meaning that we take the hierarchical structure of the data into account but do not treat any of the individual level predictors as random effects (Hox, 2002). As shown in Table 2 and Table 3, we estimate stepwise models, subsequently including minority status and the control variables, then the socio-economic position variables, then the civic and social participation variables, and in the fourth model the neighbourhood characteristics. Regarding political trust, the fourth model also includes the political orientation variables. Table 4 shows the results of additional analyses, in which we added the variables that are specifically relevant for minorities. To obtain an indication of the amount of variance explained in the analyses, we have first estimated empty models (not presented). The thus obtained estimates of the 'initial' variance components at the individual and neighbourhood levels are used to calculate the per cent of explained variance at both levels for each model.

\section{Results}

\section{Measurement invariance}

We tested the measurement invariance of the dependent variables between natives and minorities with Confirmatory Factor Analysis in MPLUS. Regarding generalized trust, the weak invariance model (constraining the factor loadings to be equal among natives and minorities) fitted the data reasonably well (RMSEA=.074, CFI=.990). The $\mathrm{Chi}^{2}$ difference test did indicate, however, that the model with invariant loadings fitted the data significantly more poorly than the unconstrained model $\left(\mathrm{Chi}^{2}\right.$ difference $\left.=23.548, \mathrm{df}=2, \mathrm{p}<.001\right)$. Inspection of the factors loadings indicates that especially the loading for the item 'You can't be too careful in dealing with people' is lower among immigrants. 
Regarding trust in political institutions, the model with invariant loadings fitted the data very well ( $\mathrm{RMSEA}=.026, \mathrm{CFI}=.999)$. The $\mathrm{Chi}^{2}$ difference test again indicated, however, that the model with invariant loadings fitted the data significantly more poorly than the unconstrained model $\left(\mathrm{Chi}^{2}\right.$ difference $\left.=11.221, \mathrm{df}=3, \mathrm{p}=.011\right)$. Further analyses show that a partial weak invariance model in which the loading of the 'politics' item is left unconstrained does not fit the data more poorly than the unconstrained model. Moreover, a partial strong invariance model in which the loading and intercept of both the 'politics' and the 'European Union' items are left unconstrained also does not fit the data more poorly than the unconstrained model. Inspection of the factors loadings and intercepts indicates that the loading for the 'politics' item is lower among immigrants, and that the (low) intercepts for the 'politics' and the 'European Union' items among minorities correspond differently to the mean of the latent construct than among natives. The poorer performance of these two items is potentially related to the strong anti-immigrant rhetoric by some politicians in the Netherlands and on the European level, which should be reflected less in immigrants' assessments of the government and of the police and justice department (i.e. the other items).

In the literature on measurement invariance, the idea is broadly supported that strong measurement invariance warrants meaningful comparison of factor means across groups, and that partial invariance at this level (at least two items per factor exhibit strong invariance) can be considered a sufficient condition (Steenkamp and Baumgartner, 1998). Our results thus indicate that we can validly compare trust in political institutions. On the other hand, even though the indicators form reliable measures of generalized trust, we do have to take into account that weak (or strong) invariance could not be established, and consequently that the items measuring generalized trust do not mean exactly the same to natives as they do to minorities. This is in line with criticisms of this type of trust questions, which argue that respondents may take different 'imagined communities' in mind when asked about 'most people', ranging from all people in the world to most people they know personally (Delhey, Newton and Welzel, 2011; Sturgis and Smith, 2010). It may be the case that this systematically differs between immigrants and natives, because 'most people' will more strongly connote 'outgroups' in society to immigrants than it does to natives.

\section{Multilevel regression models of generalized trust}

Regarding generalized trust, the results do provide support for our first hypothesis. We find that the relations between the immigrant group variables and generalized trust remain 
significant in each model of Table 2 . While the effects become smaller by adding new variables, they do remain significant also in the full Model 4.

Regarding socio-economic position, Table 2 shows that education level and occupational status are positively related to generalized trust, while having financial problems relates negatively to generalized trust. Regarding civic participation and social resources, the results show that generalized trust is higher among those who are active in voluntary organizations, among those who have more social resources (i.e. feel more integrated and less isolated), and among those who perceive more neighbourhood collective efficacy. Furthermore, the results of Model 4 in Table 2 indicate that trust is higher among residents of higher-income neighbourhoods, but including the neighbourhood level variables does not have much influence on the relations between the minority group variables and generalized trust. A test of interaction effects between minority status and the other independent variables shows that the main correlates of generalized trust do not differ much between natives and minorities, though the positive effects of education and occupational status are stronger among natives than among minorities (online appendix, Table A.2). ${ }^{4}$

- Table 2 about here -

\section{Multilevel regression models of trust in political institutions}

A different picture arises when we look at trust in political institutions (Table 3). For this kind of trust, the results provide support for hypothesis 2 as the initial differences largely become non-significant in Model 4. We find that the relations between the minority group variables and trust in political institutions only remain significant for second generation Moroccan minorities, and to a lesser extent first generation Turkish minorities (Models 1-4, Table 3). Moreover, trust in political institutions is clearly related to socio-economic position, to civic participation and social resources, and to respondents' political orientation.

Regarding socio-economic position, Model 2 in Table 3 shows that education level and occupational status are positively related to trust in political institutions, while having financial problems relates negatively to trust in political institutions. Moreover, trust in political institutions is higher among students. The relations between the minority group variables and trust in political institutions are substantially reduced by including the socioeconomic variables in the second model of Table 3, lending support to our third hypothesis.

Regarding civic participation and social resources, the results show that trust in political institutions is higher among those who are active in voluntary organizations, among 
those who have more social resources (i.e. feel more integrated), and among those who perceive more neighbourhood collective efficacy. The relations between the minority group variables and trust in political institutions are further reduced by including the variables for civic participation and social resources in Model 3 of Table 3.

Regarding hypothesis 4, the results in Table 3 (Model 4) indicate that trust in political institutions is largely unrelated to the neighbourhood level variables. The results in the fourth model of Table 3 also indicate, however, that trust in political institutions is positively related to being interested in politics and having a preference for one of the ruling parties in the last elections. Interestingly, including the political variables does not further reduce the relations between the immigrant group variables and trust in political institutions, in contrast to our fifth hypothesis. Conversely, the relations between the immigrant group variables and trust in political institutions become larger, because immigrant group members more often had a preference for one of the ruling parties, and also because interest in politics is relatively high among second generation Moroccans (see Table 1).

When comparing the correlates of trust in political institutions between natives and minorities using interaction effects, we see both parallel and contrasting effects (online appendix, Table A.2). For both natives and minorities, trust in political institutions is negatively related to having financial problems, and positively related to social resources (i.e. feeling integrated), interest in politics, and having a preference for one of the ruling parties. On the other hand, unemployment, occupational status, and education significantly affect trust in political institutions among natives but not among minorities.

- Table 3 about here -

\section{Minority-specific determinants of trust}

To investigate the main correlates of generalized trust and trust in political institutions among minorities more in depth, we turn to the results presented in Table 4. From the first model in Table 4, it becomes clear that of the variables that are specifically relevant for minorities, only perceived discrimination is significantly related to generalized trust. Regarding trust in political institutions, the variables that apply specifically to minorities have more impact. Discrimination and identification with the host country are among the most important correlates of minorities' trust in political institutions, as can be seen in the second model of Table 4. 
- Table 4 about here -

\section{Discussion}

In this study we set out to investigate whether immigrant minorities' levels of generalized trust and trust in political institutions are lower than those of natives, and to what extent the differences in trust between natives and minorities remain significant when controlling for important correlates of trust. In accordance with our hypotheses, immigrant minority members display significantly lower levels of generalized trust. For trust in political institutions, on the other hand, most of the initially observed difference is rendered nonsignificant in the full multivariate and multilevel model.

In light of the remaining difference in generalized trust levels between natives and minorities, therefore, our study suggests that both cultural explanations (such as religiosity) and learning experiences (such as perceived group discrimination and traumatic experiences) should be investigated further in future studies. The main conclusion of this study is therefore that socio-economic position and civic and social participation are indeed related to levels of trust. Because we find that factors such as education and perceived neighbourhood collective efficacy do also affect generalized trust, our results suggest that policies aiming to improve immigrants' economic and social integration will generally be conducive to immigrants' psychological attachment to society.

It has to be noted that metric (or higher) measurement equivalence between natives and minorities could not be established for the generalized trust variable. This implies that caution is required in comparing the generalized trust levels between groups. We do use straightforward indicators of generalized trust, however, similar to national and cross-national studies that did find generalized trust to be equivalent across groups (Dinesen, 2011; Reeskens and Hooghe, 2008). On the other hand, other researchers have raised doubts regarding this type of trust questions, because it has been shown that respondents may take different 'imagined communities' in mind when asked about 'most people', ranging from all people in the world to most people they know personally. Our results suggest that forms of trust that refer to specific actors, institutions or domains can be more confidently compared between minorities and the majority group.

The analysis demonstrates that immigrant minorities do not have significantly lower levels of trust in political institutions than native Dutch, once economic position, civic and social participation, and political orientation are taken into account. Only the second 
generation Moroccan minorities deviate in this regard. Our study furthermore shows that minorities' trust in political institutions, and to a lesser extent generalized trust, is heavily influenced by feelings of personal discrimination. Unfortunately, we cannot compare natives and minorities in this regard, since the discrimination question was not asked to the native respondents. Inspection of the data does reveal that perceived discrimination is especially high among second generation Moroccans. In line with the argument already made by Rothstein and Stolle (2003), it is tempting therefore to investigate the relation between perceived discrimination in the hands of authorities and levels of political trust among this group. Our findings are compatible with earlier findings showing that trust is lower among discriminated groups (Alesina and La Ferrara, 2002; Michelson, 2003; Smith, 2010).

It has to be remembered that in this case too, data collection was only conducted in one language. This implies that ethnic minority members that do not have a sufficient level of Dutch to participate in the survey were not included in the sample. It remains to be investigated, therefore, whether the current findings could be generalized toward the entire community of immigrant minorities, including those who do not have much knowledge of the language of their host society. How exactly one could conduct in a valid manner such a survey in multiple languages, however, does remain a cause for concern and further investigation. Further, given the cross-sectional nature of the dataset, we do not have information on the trust levels of ethnic minorities before they immigrated. This means that we cannot account for the possible selectivity in trust of those who have migrated to the Netherlands. Furthermore, future studies that can benefit from a double comparative research design, with multiple origin and destination countries, will be more suited to distinguish origin and destination effects and will also provide yet a better test of the persistence and lifelong learning hypotheses. It has to be noted that this study was limited to one country, and future research should determine whether similar patterns can be found in other countries in Western Europe. 


\section{References}

Alesina, A. and La Ferrara, E. (2002). Who trusts others? Journal of Public Economics, 85, $207-234$.

Aleksynska, M. (2011). Civic participation of immigrants in Europe. Assimilation, origin, and destination country effects. European Journal of Political Economy, 27, 566-585.

De Graaf, P.M., Kalmijn, M., Kraaykamp, G. and Monden, C.W.S. (2010a). The NEtherlands Longitudinal Lifecourse Study (NELLS Wave 1). Dataset. Tilburg University and Radboud University Nijmegen, Netherlands.

De Graaf, P.M., Kalmijn, M., Kraaykamp, G. and Monden, C.W.S. (2010b). Design and content of the NEtherlands Longitudinal Lifecourse Study (NELLS). Research report. Tilburg University and Radboud University Nijmegen, Netherlands.

Delhey, J. and Newton, K. (2005). Predicting cross-national levels of social trust: Global patterns or Nordic exceptionalism? European Sociological Review, 21(4), 311-327.

Delhey, J., Newton, K. and Welzel, C. (2011). How general is trust in "most people"? Solving the radius of trust problem. American Sociological Review, 76, 786-807.

Dinesen, P.T. (2011). A note on the measurement of generalized trust of immigrants and natives. Social Indicators Research, 103, 169-177.

Dinesen, P.T. (2012). Where you come from or where you live? Examining the cultural and institutional explanation of generalized trust using migration as a natural experiment. European Sociological Review, Online First, doi: 10.1093/esr/jcr044.

Dinesen, P.T. and Hooghe, M. (2010). When in Rome, do as the Romans do. The acculturation of generalized trust among immigrants in Europe. International Migration Review, 44, 697-727.

Easton, D. (1965). A framework for political analysis. Englewood Cliffs: Prentice Hall 
Esser, H. (2003). What substance is there in the term 'Leitkultur'? In: Cuperus, R., Duffek, K.A. and Kandel, J. (Eds.), The Challenge of Diversity. Innsbruck: Studienverlag, pp. 47-58.

Fennema, M. and Tillie, J. (2001). Civic community, political participation and political trust of ethnic groups. Connections, 24, 26-41.

Fennema, M. and Tillie, J. (1999). Political participation and political trust in Amsterdam: civic communities and ethnic networks. Journal of Ethnic and Migration Studies, 25, 703-726.

Ganzeboom, H.B.G., De Graaf, P.M. and Treiman, D.J. (1992). A standard international socio-economic index of occupational status. Social Science Research, 21, 1-56.

Gijsberts, M., Van der Meer, T. and Dagevos, J. (2012). 'Hunkering down' in multi-ethnic neighbourhoods? The effects of ethnic diversity on dimensions of social cohesion. European Sociological Review, 28, 527-537.

Hooghe, M. (2007). Social capital and diversity. Generalized trust, social cohesion and regimes of diversity. Canadian Journal of Political Science, 40, 709-732.

Hox, J. (2002). Multilevel Analysis: Techniques and Applications. Mahwah: Lawrence Erlbaum Associates.

Kumlin, S. and Rothstein, B. (2010). Questioning the new liberal dilemma. Immigrants, social trust and institutional fairness. Comparative Politics, 43, 63-80.

Lancee, B. and Dronkers, J. (2011). Ethnic, religious and economic diversity in Dutch neighbourhoods: Explaining quality of contact with neighbours, trust in the neighbourhood and inter-ethnic trust. Journal of Ethnic and Migration Studies, 37, 597 618.

Marien, S. (2011). Measuring political trust across time and space. In: Zmerli, S. and Hooghe, M. (Eds.), Political Trust. Why Context Matters. Colchester: ECPR Press, pp. $13-46$. 
Marien, S. and Hooghe, M. (2011). Does political trust matter? An empirical investigation into the relation between political trust and support for law compliance. European Journal of Political Research, 50(2), 267-91.

McLaren, L. (2012). Immigration and Trust in Politics in Britain, British Journal of Political Science, 42(1), 163-185.

Michelson, M.R. (2003). The corrosive effect of acculturation: How Mexican Americans lose political trust. Social Science Quarterly, 84(4), 918-933.

Nannestad, P. (2008). What have we learned about generalized trust, if anything? Annual Review of Political Science, 11, 413-436.

Newton, K. (1997). Social capital and democracy. American Behavioral Scientist, 40, 575586.

Putnam, R. (1993). Making democracy work. Civic traditions in modern Italy. Princeton: Princeton University Press.

Putnam, R. (2000). Bowling alone. New York: Simon \& Schuster.

Putnam, R. (2007). E pluribus unum. Diversity and community in the twenty-first century. Scandinavian Political Studies, 30, 137-174.

Reeskens, T. and Hooghe, M. (2008). Cross-cultural measurement equivalence of generalized trust. Evidence from the European Social Survey (2002 and 2004). Social Indicators Research, 85, 515-532.

Rothstein, B. and Stolle, D. (2003). Social capital, impartiality, and the welfare state: An institutional approach. In: Hooghe, M. and Stolle, D. (Eds.), Generating Social Capital: Civil Society and Institutions in Comparative Perspective. New York: Palgrave/Macmillan, pp. 191-210.

Sampson, R.J., Raudenbush, S.W. and Earls, F. (1997). Neighborhoods and violent crime: A multilevel study of collective efficacy. Science, 277, 918-924. 
Savelkoul, M., Gesthuizen, M. and Scheepers, P. (2011). Explaining relationships between ethnic diversity and informal social capital across European countries and regions: Tests of constrict, conflict and contact theory. Social Science Research, 40, 1091-1107.

Smith, S.S. (2010). Race and trust. Annual Review of Sociology, 36, 453-475.

Steenkamp, J. E. and Baumgartner, H. (1998). Assessing measurement invariance in crossnational consumer research. Journal of Consumer Research, 25, 78-90.

Sturgis, P. and Smith, P. (2010). Assessing the validity of generalized trust questions: what kind of trust are we measuring? International Journal of Public Opinion Research, 22, 74-92.

Uslaner, E.M. (2002). The Moral Foundations of Trust. Cambridge: Cambridge University Press.

Uslaner, E.M. (2008). Where you stand depends upon where your grandparents sat. Public Opinion Quarterly, 72, 725-740.

Wilkes, R. (2011). Re-thinking the decline in trust: A comparison of black and white Americans. Social Science Research, 40, 1596-1610.

Zmerli, S. and Hooghe, M. (Eds.) (2011). Political Trust. Why Context Matters. Colchester: ECPR Press. 
Table 1: Descriptive statistics of dependent and independent variables

\begin{tabular}{|c|c|c|c|c|c|c|c|c|c|c|c|}
\hline & \multirow[b]{2}{*}{ Range } & \multicolumn{2}{|c|}{ Natives } & \multicolumn{2}{|c|}{$\begin{array}{c}1^{\text {st }} \text { gen. } \\
\text { Moroccan }\end{array}$} & \multicolumn{2}{|c|}{$\begin{array}{c}2^{\text {nd }} \text { gen. } \\
\text { Moroccan }\end{array}$} & \multicolumn{2}{|c|}{$\begin{array}{l}1^{\text {st }} \text { gen. } \\
\text { Turkish }\end{array}$} & \multicolumn{2}{|c|}{$\begin{array}{l}2^{\text {nd }} \text { gen. } \\
\text { Turkish }\end{array}$} \\
\hline & & Mean & SD & Mean & $\mathrm{SD}$ & Mean & $\mathrm{SD}$ & Mean & SD & Mean & SD \\
\hline \multicolumn{12}{|l|}{ Dependent variables } \\
\hline Generalized trust & $0-4$ & 2.10 & .70 & 1.71 & .69 & 1.80 & 69 & 1.70 & .68 & 1.69 & .65 \\
\hline Political trust & $0-3$ & 1.37 & .55 & 1.22 & .66 & 1.27 & .58 & 1.18 & .63 & 1.29 & .67 \\
\hline \multicolumn{12}{|c|}{ Individual characteristics (level 1) } \\
\hline Female & $0 / 1$ & .54 & & .54 & & .58 & & 48 & & .54 & \\
\hline Age & $14-49$ & 31.66 & 9.07 & 34.41 & 6.88 & 22.85 & 6.53 & 35.58 & 7.56 & 24.47 & 7.39 \\
\hline Has a partner & $0 / 1$ & .60 & & .69 & & .22 & & .70 & & .36 & \\
\hline Education level & $0-5$ & 3.14 & 1.03 & 2.16 & 1.35 & 2.71 & 1.02 & 2.30 & 1.32 & 2.69 & 1.01 \\
\hline Education in other country ${ }^{a}$ & $0 / 1$ & $<.01$ & & .28 & & .01 & & .42 & & .02 & \\
\hline \multicolumn{12}{|l|}{ Prof. Activity } \\
\hline Currently employed & $0 / 1$ & .73 & & .57 & & .35 & & .62 & & .43 & \\
\hline Currently unemployed & $0 / 1$ & .03 & & .08 & & .04 & & .10 & & .08 & \\
\hline Non-labour-force & $0 / 1$ & .05 & & .28 & & .08 & & .22 & & .08 & \\
\hline Currently student & $0 / 1$ & .19 & & .07 & & .53 & & .07 & & .41 & \\
\hline Occupational status & $22-88$ & 48.43 & 12.86 & 43.63 & 8.65 & 47.32 & 7.97 & 44.06 & 10.52 & 46.38 & 9.25 \\
\hline Supervisor at work & $0 / 1$ & .24 & & .13 & & .09 & & .19 & & .12 & \\
\hline Financial problems & $0-5$ & .42 & .88 & 1.12 & 1.42 & .63 & 1.09 & 1.16 & 1.44 & .90 & 1.30 \\
\hline \multicolumn{12}{|l|}{ Associations } \\
\hline Assoc - none & $0 / 1$ & .24 & & .45 & & .31 & & .44 & & .38 & \\
\hline Assoc - only member & $0 / 1$ & .40 & & .35 & & .49 & & .31 & & .46 & \\
\hline Assoc - volunteer & $0 / 1$ & .36 & & .20 & & .20 & & .24 & & .16 & \\
\hline Feels integrated & $0-3$ & 2.20 & .53 & 2.06 & .61 & 2.11 & .62 & 1.95 & .60 & 2.03 & .61 \\
\hline Feels isolated & $0-3$ & .76 & .60 & 1.06 & .66 & .83 & .60 & 1.12 & .59 & .95 & .65 \\
\hline Outgroup friends & $0 / 1$ & .40 & & .79 & & .93 & & .78 & & .92 & \\
\hline Perceived collective efficacy & $0-3$ & 2.42 & .56 & 2.28 & .60 & 2.33 & .56 & 2.20 & .59 & 2.27 & .56 \\
\hline Left-right scale $^{b}$ & $0-10$ & 5.17 & 2.04 & 3.84 & 2.07 & 3.61 & 2.20 & 4.21 & 2.12 & 4.27 & 2.04 \\
\hline Interested in politics ${ }^{\mathrm{b}}$ & $0-2$ & .69 & .61 & .71 & .68 & .85 & .60 & .57 & .65 & .58 & .62 \\
\hline Preference for ruling party ${ }^{b}$ & $0 / 1$ & .34 & & .47 & & .45 & & .44 & & .41 & \\
\hline Perceived discrimination $^{\mathrm{c}}$ & $0-2$ & & & .31 & .40 & .41 & .43 & .33 & .40 & .30 & .37 \\
\hline National identification $^{c}$ & $0-4$ & & & 2.74 & .82 & 2.75 & .81 & 2.51 & .79 & 2.67 & .74 \\
\hline Dutch language proficiency $^{\mathrm{c}}$ & $0-4$ & & & 3.03 & 1.00 & 3.84 & .38 & 2.82 & 1.03 & 3.64 & .62 \\
\hline Years spent in the Netherlands ${ }^{c}$ & $0-45$ & & & 19.72 & 9.29 & 22.85 & 6.53 & 20.76 & 10.24 & 24.47 & 7.39 \\
\hline Dutch nationality ${ }^{\mathrm{c}}$ & $0 / 1$ & & & .71 & & 1.00 & & .68 & & 1.00 & \\
\hline \multicolumn{12}{|c|}{ Neighbourhood characteristics (level 2) } \\
\hline Proportion Non-Western res. & $0-.85$ & .09 & .09 & .29 & .19 & .26 & .18 & .27 & .19 & .25 & .15 \\
\hline Average income level & $8.2-24.4$ & 12.92 & 1.32 & 12.33 & 1.58 & 12.54 & 1.54 & 12.34 & 1.65 & 12.38 & 1.42 \\
\hline $\mathrm{N}$ & & 2,381 & & 585 & & 344 & & 578 & & 334 & \\
\hline
\end{tabular}

Source: NELLS (De Graaf et al., 2010a)

Notes: ${ }^{\mathrm{a}}$ Less than one percent of the natives in our sample followed education abroad. ${ }^{\mathrm{b}}$ Only included in the analyses of trust in political institutions. ${ }^{\mathrm{c}}$ Minority-specific variable. 
Table 2: Multilevel models of generalized trust, $\mathrm{N}=4,222$

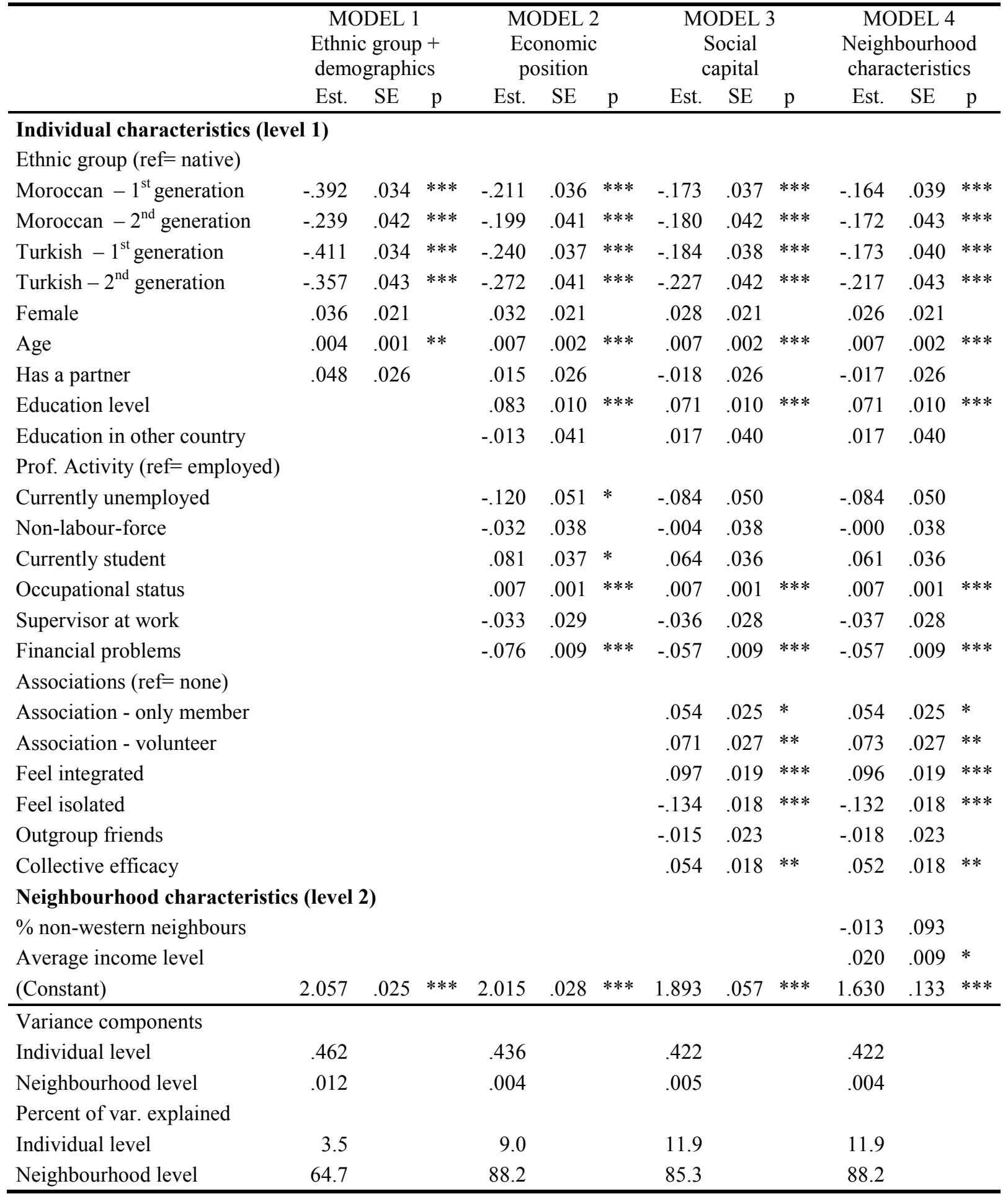

Source: NELLS (De Graaf et al., 2010a).

$* * *$ Significant at $\mathrm{p}<.001 ; * *$ significant at $\mathrm{p}<.01$; *significant at $\mathrm{p}<.05$. 
Table 3: Multilevel models of political trust, $\mathrm{N}=4,222$

\begin{tabular}{|c|c|c|c|c|c|c|c|c|c|c|c|c|}
\hline & \multicolumn{3}{|c|}{$\begin{array}{c}\text { MODEL 1 } \\
\text { Ethnic group }+ \\
\text { demographics }\end{array}$} & \multicolumn{3}{|c|}{$\begin{array}{l}\text { MODEL 2 } \\
\text { Economic } \\
\text { position }\end{array}$} & \multicolumn{3}{|c|}{$\begin{array}{c}\text { MODEL } 3 \\
\text { Social } \\
\text { capital }\end{array}$} & \multicolumn{3}{|c|}{$\begin{array}{c}\text { MODEL 4 } \\
\text { Political } \\
\text { orientation }\end{array}$} \\
\hline & Est. & SE & $\mathrm{p}$ & Est. & SE & $\mathrm{p}$ & Est. & SE & $\mathrm{p}$ & Est. & SE & $\mathrm{p}$ \\
\hline \multicolumn{13}{|c|}{ Individual characteristics (level 1) } \\
\hline \multicolumn{13}{|l|}{ Ethnic group (ref= native) } \\
\hline Moroccan $-1^{\text {st }}$ generation & -.143 & .029 & $* * *$ & -.016 & .031 & & .004 & .032 & & -.056 & .033 & \\
\hline Moroccan $-2^{\text {nd }}$ generation & -.160 & .036 & $* * *$ & -.133 & .035 & $* * *$ & -.116 & .035 & ** & -.181 & .037 & $* * *$ \\
\hline Turkish $-1^{\text {st }}$ generation & -.173 & .029 & $* * *$ & -.073 & .032 & $*$ & -.040 & .033 & & -.078 & .034 & $*$ \\
\hline Turkish $-2^{\text {nd }}$ generation & -.122 & .036 & $* *$ & -.052 & .035 & & -.021 & .037 & & -.049 & .037 & \\
\hline Female & .089 & .018 & $* * *$ & .086 & .018 & $* * *$ & .074 & .018 & $* * *$ & .088 & .018 & *** \\
\hline Age & -.007 & .001 & $* * *$ & -.001 & .001 & & -.001 & .001 & & -.002 & .001 & \\
\hline Has a partner & .013 & .022 & & .008 & .022 & & -.005 & .022 & & -.006 & .022 & \\
\hline Education level & & & & .061 & .009 & $* * *$ & .054 & .009 & $* * *$ & .046 & .009 & $* * *$ \\
\hline Education in other country & & & & .093 & .034 & ** & .106 & .034 & $* *$ & .131 & .034 & $* * *$ \\
\hline \multicolumn{13}{|l|}{ Prof. Activity (ref $=$ employed) } \\
\hline Currently unemployed & & & & -.090 & .043 & $*$ & -.069 & .043 & & -.072 & .042 & \\
\hline Non-labour-force & & & & -.015 & .032 & & -.003 & .032 & & -.009 & .032 & \\
\hline Currently student & & & & .213 & .031 & $* * *$ & .203 & .031 & $* * *$ & .193 & .031 & *** \\
\hline Occupational status & & & & .004 & .001 & $* * *$ & .004 & .001 & $* * *$ & .004 & .001 & $* * *$ \\
\hline Supervisor at work & & & & -.028 & .024 & & -.026 & .024 & & -.036 & .024 & \\
\hline Financial problems & & & & -.071 & .008 & $* * *$ & -.062 & .008 & $* * *$ & -.062 & .008 & $* * *$ \\
\hline \multicolumn{13}{|l|}{ Associations (ref $=$ none) } \\
\hline Association - only member & & & & & & & .048 & .021 & $*$ & .040 & .021 & \\
\hline Association - volunteer & & & & & & & .061 & .023 & $* *$ & .045 & .023 & \\
\hline Feel integrated & & & & & & & .102 & .016 & $* * *$ & .095 & .016 & $* * *$ \\
\hline Feel isolated & & & & & & & -.014 & .015 & & -.010 & .015 & \\
\hline Outgroup friends & & & & & & & -.019 & .020 & & -.022 & .020 & \\
\hline Collective efficacy & & & & & & & .051 & .016 & ** & .054 & .016 & ** \\
\hline Left-right scale & & & & & & & & & & -.008 & .004 & \\
\hline Interested in politics & & & & & & & & & & .096 & .015 & $* * *$ \\
\hline Preference for ruling party & & & & & & & & & & .145 & .018 & $* * *$ \\
\hline \multicolumn{13}{|c|}{ Neighbourhood characteristics (level 2) } \\
\hline$\%$ non-western neighbours & & & & & & & & & & .082 & .087 & \\
\hline Average income level & & & & & & & & & & .009 & .008 & \\
\hline (Constant) & 1.322 & .022 & $* * *$ & 1.244 & .024 & $* * *$ & 1.220 & .030 & $* * *$ & 1.033 & .118 & $* * *$ \\
\hline \multicolumn{13}{|l|}{ Variance components } \\
\hline Individual level & .331 & & & .311 & & & .305 & & & .298 & & \\
\hline Neighbourhood level & .012 & & & .008 & & & .008 & & & .007 & & \\
\hline \multicolumn{13}{|l|}{ Percent of var. explained } \\
\hline Individual level & 2.9 & & & 8.8 & & & 10.6 & & & 12.6 & & \\
\hline Neighbourhood level & $<0.1$ & & & 27.3 & & & 27.3 & & & 36.4 & & \\
\hline
\end{tabular}

Source: NELLS (De Graaf et al., 2010a).

$* * *$ Significant at $\mathrm{p}<.001 ; * *$ significant at $\mathrm{p}<.01 ; *$ significant at $\mathrm{p}<.05$. 
Table 4: Multilevel models of trust among immigrant minorities, $\mathrm{N}=1,841$

\begin{tabular}{|c|c|c|c|c|c|c|}
\hline \multirow{4}{*}{$\begin{array}{l} \\
\text { Individual characteristics (level }\end{array}$} & \multicolumn{3}{|c|}{$\begin{array}{c}\text { MODEL } 1 \\
\text { Generalized trust }\end{array}$} & \multicolumn{3}{|c|}{$\begin{array}{c}\text { MODEL } 2 \\
\text { Political trust }\end{array}$} \\
\hline & \multirow[t]{2}{*}{ Est. } & \multirow[t]{2}{*}{ SE } & \multirow[t]{2}{*}{$\mathrm{p}$} & \multirow[t]{2}{*}{ Est. } & \multirow[t]{2}{*}{$\mathrm{SE}$} & \multirow[t]{2}{*}{$\mathrm{p}$} \\
\hline & & & & & & \\
\hline & & & & & & \\
\hline Moroccan $-1^{\text {st }}$ generation & .078 & .060 & & -.065 & .054 & \\
\hline Moroccan $-2^{\text {nd }}$ generation & .066 & .052 & & -.082 & .048 & \\
\hline Turkish $-1^{\text {st }}$ generation & .053 & .059 & & -.069 & .053 & \\
\hline \multicolumn{7}{|l|}{ Turkish $-2^{\text {nd }}$ generation ( $=$ ref.) } \\
\hline Female & -.003 & .034 & & .063 & .031 & $*$ \\
\hline Age & .003 & .004 & & -.000 & .003 & \\
\hline Has a partner & -.057 & .039 & & -.011 & .036 & \\
\hline Education level & .043 & .015 & ** & .025 & .014 & \\
\hline Education in other country & -.005 & .052 & & -.011 & .047 & \\
\hline \multicolumn{7}{|l|}{ Prof. Activity (ref $=$ employed) } \\
\hline Currently unemployed & -.112 & .064 & & -.003 & .057 & \\
\hline Non-labour-force & -.004 & .051 & & .014 & .046 & \\
\hline Currently student & -.102 & .058 & & .151 & .053 & $* *$ \\
\hline Occupational status & .007 & .002 & $* * *$ & .003 & .002 & \\
\hline Supervisor at work & -.040 & .050 & & -.054 & .045 & \\
\hline Financial problems & -.064 & .012 & $* * *$ & -.056 & .011 & $* * *$ \\
\hline \multicolumn{7}{|l|}{ Associations (ref= none) } \\
\hline Association - only member & .017 & .036 & & .038 & .032 & \\
\hline Association - volunteer & .051 & .043 & & .055 & .039 & \\
\hline Feel integrated & .057 & .027 & * & .049 & .025 & $*$ \\
\hline Feel isolated & -.094 & .026 & $* * *$ & .035 & .024 & \\
\hline Outgroup friends & -.013 & .045 & & .027 & .041 & \\
\hline Collective efficacy & .047 & .028 & & .070 & .025 & $* *$ \\
\hline Left-right scale & & & & .004 & .007 & \\
\hline Interested in politics & & & & .116 & .023 & $* * *$ \\
\hline Preference for ruling party & & & & .108 & .029 & $* * *$ \\
\hline Perceived discrimination & -.097 & .042 & $*$ & -.279 & .038 & $* * *$ \\
\hline National identification & -.027 & .021 & & .103 & .019 & $* * *$ \\
\hline Dutch language proficiency & -.009 & .025 & & -.070 & .023 & $* *$ \\
\hline Years spent in the Netherlands & .001 & .003 & & -.004 & .003 & \\
\hline Dutch nationality & .082 & .047 & & .028 & .043 & \\
\hline \multicolumn{7}{|c|}{ Neighbourhood characteristics (level 2) } \\
\hline$\%$ non-western neighbours & -.215 & .123 & & -.161 & .135 & \\
\hline Average income level & -.000 & .014 & & -.010 & .014 & \\
\hline (Constant) & 1.762 & .221 & $* * *$ & 1.116 & .228 & $* * *$ \\
\hline \multicolumn{7}{|l|}{ Variance components } \\
\hline Individual level & .428 & & & .341 & & \\
\hline Neighbourhood level & .003 & & & .014 & & \\
\hline \multicolumn{7}{|l|}{ Percent of var. explained } \\
\hline Individual level & 6.3 & & & 14.1 & & \\
\hline Neighbourhood level & 70.0 & & & $<.01$ & & \\
\hline
\end{tabular}

Source: NELLS (De Graaf et al., 2010a).

***Significant at $\mathrm{p}<.001 ; * *$ significant at $\mathrm{p}<.01 ; *$ significant at $\mathrm{p}<.05$. 


\section{Endnotes}

1. Analyses were also conducted with a different operationalization, where the unemployed were entered as a distinct category. Results of the analysis, however, were identical.

2. Unfortunately, the discrimination questions were not asked to the native Dutch, so we cannot include discrimination in the analyses for the full sample.

${ }^{3}$. It should be noted that most second generation immigrants have sufficient proficiency in the Dutch language, all second generation minorities hold the Dutch nationality, and years in the Netherlands is equal to age for second generation minorities.

${ }^{4}$. Additionally, we have results for interaction effects with all four minority group dummies available upon request (alternative to Tables A.2). These results lead to the same substantive conclusions, because the relations differ little between the minority groups. 


\section{Online Appendix}

Table A.1: Correlations - All respondents $>>$ part 1

\begin{tabular}{|c|c|c|c|c|c|c|c|c|c|c|c|c|c|c|}
\hline & 1 & 2 & 3 & 4 & 5 & 6 & 7 & 8 & 9 & 10 & 11 & 12 & 13 & 14 \\
\hline 1. Generalized trust & 1 & $.273^{* *}$ & .028 & $.058^{* *}$ & $.059^{* *}$ & $.266^{* *}$ & $-.119^{* *}$ & $.104^{* *}$ & $-.094^{* *}$ & $-.095^{* *}$ & .000 & $.212^{* *}$ & $.059^{* *}$ & $-.210^{* *}$ \\
\hline 2. Political trust & & 1 & $.074^{* *}$ & $-.094^{* *}$ & $-.040^{* *}$ & $.200^{* *}$ & $-.043^{* *}$ & $-.047^{* *}$ & $-.086^{* *}$ & $-.060^{* *}$ & $.150^{* *}$ & $.146^{* *}$ & -.024 & $-.188^{* *}$ \\
\hline 3. Female & & & 1 & -.022 & $.050^{* *}$ & -.001 & -.021 & $-.113^{* *}$ & -.007 & $.185^{* *}$ & -.005 & .019 & $-.177^{* *}$ & -.025 \\
\hline 4. Age & & & & 1 & $.538^{* *}$ & -.024 & $.179^{* *}$ & $.459^{* *}$ & .021 & $.127^{* *}$ & $-.660^{* *}$ & .021 & $.236^{* *}$ & $.064^{* *}$ \\
\hline 5. Partner & & & & & 1 & $.048^{* *}$ & $.160^{* *}$ & $.425^{* *}$ & $-.061^{* *}$ & $.058^{* *}$ & $-.521^{* *}$ & $.039^{*}$ & $.191^{* *}$ & $-.049^{* *}$ \\
\hline 6. Education & & & & & & 1 & $-.170^{* *}$ & $.207^{* *}$ & $-.111^{* *}$ & $-.294^{* *}$ & $.042^{* *}$ & $.372^{* *}$ & $.123^{* *}$ & $-.194^{* *}$ \\
\hline 7. Education in $\mathrm{OC}$ & & & & & & & 1 & $-.038^{*}$ & $.042^{* *}$ & $.241^{* *}$ & $-.165^{* *}$ & $-.155^{* *}$ & $-.039^{*}$ & $.143^{* *}$ \\
\hline 8. Employed & & & & & & & & 1 & a & a & $\mathrm{a}$ & .000 & $.370^{* *}$ & $-.122^{* *}$ \\
\hline 9. Unemployed & & & & & & & & & 1 & a & $\mathrm{a}$ & .000 & $-.111^{* *}$ & $.171^{* *}$ \\
\hline 10. Non-labour-force & & & & & & & & & & 1 & a & .000 & $-.174^{* *}$ & $.138^{* *}$ \\
\hline 11. Student & & & & & & & & & & & 1 & .000 & $-.248^{* *}$ & $-.052^{* *}$ \\
\hline 12. Occupational status & & & & & & & & & & & & 1 & $.131^{* *}$ & $-.115^{* *}$ \\
\hline 13. Supervisor & & & & & & & & & & & & & 1 & $-.086^{* *}$ \\
\hline 14. Financial problems & & & & & & & & & & & & & & 1 \\
\hline 15. No member & $-.137^{* *}$ & $-.110^{* *}$ & $.050^{* *}$ & $.041^{* *}$ & $.033^{*}$ & $-.207^{* *}$ & $.121^{* *}$ & $-.051^{* *}$ & $.096^{* *}$ & $.128^{* *}$ & $-.090^{* *}$ & $-.126^{* *}$ & $-.045^{* *}$ & $.103^{* *}$ \\
\hline 16. Member & .030 & $.035^{*}$ & $-.047^{* *}$ & $-.086^{* *}$ & $-.062^{* *}$ & $.073^{* *}$ & $-.067^{* *}$ & .029 & $-.041^{* *}$ & $-.086^{* *}$ & $.055^{* *}$ & $.036^{*}$ & .019 & $-.042^{* *}$ \\
\hline 17. Volunteer & $.107^{* *}$ & $.075^{* *}$ & .000 & $.050^{* *}$ & $.033^{*}$ & $.132^{* *}$ & $-.050^{* *}$ & .021 & $-.053^{* *}$ & $-.038^{*}$ & $.032^{*}$ & $.090^{* *}$ & .025 & $-.060^{* *}$ \\
\hline 18. Integrated & $.192^{* *}$ & $.169^{* *}$ & $.089^{* *}$ & $-.037^{*}$ & $.033^{*}$ & $.175^{* *}$ & $-.111^{* *}$ & $.070^{* *}$ & $-.079^{* *}$ & $-.090^{* *}$ & .028 & $.074^{* *}$ & .012 & $-.158^{* *}$ \\
\hline 19. Isolated & $-.231^{* *}$ & $-.110^{* *}$ & $.039^{*}$ & .027 & $-.086^{* *}$ & $-.177^{* *}$ & $.164^{* *}$ & $-.114^{* *}$ & $.099^{* *}$ & $.153^{* *}$ & $-.036^{*}$ & $-.100^{* *}$ & $-.083^{* *}$ & $.234^{* *}$ \\
\hline 20. Outgroup friends & $-.110^{* *}$ & $-.037^{*}$ & $-.030^{*}$ & $-.132^{* *}$ & $-.130^{* *}$ & $-.059^{* *}$ & $.091^{* *}$ & $-.127^{* *}$ & $.053^{* *}$ & .000 & $.124^{* *}$ & -.007 & $-.037^{*}$ & $.127^{* *}$ \\
\hline 21. Collective efficacy & $.112^{* *}$ & $.073^{* *}$ & $.069^{* *}$ & $.088^{* *}$ & $.120^{* *}$ & .028 & $-.077^{* *}$ & $.080^{* *}$ & $-.052^{* *}$ & $-.038^{*}$ & $-.037^{*}$ & .007 & $.054^{* *}$ & $-.123^{* *}$ \\
\hline 22. Left-right scale & -.023 & -.016 & $-.078^{* *}$ & .008 & $.043^{* *}$ & $.058^{* *}$ & $-.093^{* *}$ & $.092^{* *}$ & $-.048^{* *}$ & $-.056^{* *}$ & $-.040^{* *}$ & .013 & $.110^{* *}$ & $-.079^{* *}$ \\
\hline 23. Interested in politics & $.116^{* *}$ & $.127^{* *}$ & $-.183^{* *}$ & $.044^{* *}$ & .014 & $.229^{* *}$ & $-.107^{* *}$ & $.076^{* *}$ & $-.046^{* *}$ & $-.101^{* *}$ & .012 & $.174^{* *}$ & $.122^{* *}$ & -.016 \\
\hline 24. Preference ruling party & -.011 & $.115^{* *}$ & .021 & .028 & .023 & $-.046^{* *}$ & .020 & -.004 & $.032^{*}$ & .000 & -.012 & -.013 & .009 & -.013 \\
\hline
\end{tabular}

a : Exclusive categories 
Table A.1b: Correlations - All respondents $>>$ part 2

\begin{tabular}{lcccccccccc}
\hline & 15 & 16 & 17 & 18 & 19 & 20 & 21 & 22 & 23 & 24 \\
\hline 15. No member & 1 & $\mathrm{a}$ & $\mathrm{a}$ & $-.095^{* *}$ & $.093^{* *}$ & $.059^{* *}$ & $-.078^{* *}$ & $-.064^{* *}$ & $-.102^{* *}$ & -.022 \\
16. Member & & 1 & $\mathrm{a}$ & .020 & -.023 & .028 & -.024 & .009 & $.035^{*}$ & -.018 \\
17. Volunteer & & & 1 & $.075^{* *}$ & $-.070^{* *}$ & $-.089^{* *}$ & $.104^{* *}$ & $.055^{* *}$ & $.066^{* *}$ & $.041^{* *}$ \\
18. Integrated & & & & 1 & $-.347^{* *}$ & -.007 & $.132^{* *}$ & .016 & $.085^{* *}$ & .009 \\
19. Isolated & & & & & 1 & $.061^{* *}$ & $-.129^{* *}$ & $-.048^{* *}$ & $-.078^{* *}$ & -.005 \\
20. Outgroup friends & & & & & & 1 & $-.070^{* *}$ & $-.177^{* *}$ & $.056^{* *}$ & .021 \\
21. Collective efficacy & & & & & & & 1 & $.074^{* *}$ & -.029 & .025 \\
22. Left-right scale & & & & & & & & 1 & .012 & $-.051^{* *}$ \\
23. Interested in politics & & & & & & & & & 1 & .012 \\
24. Preference for ruling party & & & & & & & & & & \\
\hline
\end{tabular}

${ }^{\mathrm{a}}$ : Exclusive categories 
Table A.2: Interaction effects between minority status and independent variables

\begin{tabular}{|c|c|c|c|c|c|c|}
\hline & \multicolumn{3}{|c|}{ Generalized trust } & \multicolumn{3}{|c|}{ Political trust } \\
\hline & Est. & SE & & Est. & SE & \\
\hline \multicolumn{7}{|l|}{ Individual characteristics (level 1) } \\
\hline \multicolumn{7}{|l|}{ Minority status: } \\
\hline \multicolumn{7}{|l|}{ Natives $=0$, Minorities $=1$} \\
\hline x Female & -0.015 & 0.041 & & 0.041 & 0.035 & \\
\hline x Age & 0.001 & 0.002 & & 0.004 & 0.002 & $*$ \\
\hline x Having a partner & -0.010 & 0.043 & & 0.028 & 0.036 & \\
\hline x Education level & -0.083 & 0.018 & $* * *$ & -0.115 & 0.016 & $* * *$ \\
\hline$x$ Education other country than NL & 0.039 & 0.221 & & -0.128 & 0.187 & \\
\hline \multicolumn{7}{|l|}{ Prof. Activity (ref= Employed) } \\
\hline x Currently unemployed & -0.012 & 0.104 & & 0.208 & 0.087 & $*$ \\
\hline x Non-labour-force & 0.148 & 0.075 & $*$ & 0.215 & 0.063 & $* *$ \\
\hline x Currently student & -0.128 & 0.053 & $*$ & -0.051 & 0.045 & \\
\hline x Occupational status & -0.003 & 0.002 & & -0.005 & 0.002 & $* *$ \\
\hline x Supervisor at work & -0.030 & 0.055 & & -0.055 & 0.046 & \\
\hline $\mathrm{x}$ Financial problems & -0.001 & 0.019 & & 0.016 & 0.016 & \\
\hline \multicolumn{7}{|l|}{ Associations (ref=none) } \\
\hline $\mathrm{x}$ Association - only member & -0.116 & 0.049 & $*$ & -0.071 & 0.041 & \\
\hline x Association - volunteer & -0.079 & 0.054 & & -0.074 & 0.046 & \\
\hline $\mathrm{x}$ Feels integrated & -0.117 & 0.036 & $* *$ & -0.085 & 0.030 & $* *$ \\
\hline $\mathrm{x}$ Feels isolated & 0.083 & 0.033 & $*$ & 0.094 & 0.028 & $* *$ \\
\hline $\mathrm{x}$ Outgroup friends & -0.063 & 0.051 & & -0.015 & 0.043 & \\
\hline x Perceived collective efficacy & -0.031 & 0.036 & & 0.082 & 0.031 & $* *$ \\
\hline x Left-right scale & & & & 0.040 & 0.008 & $* * *$ \\
\hline $\mathrm{x}$ Interested in politics & & & & -0.048 & 0.028 & \\
\hline $\mathrm{x}$ Preference for ruling party & & & & -0.040 & 0.036 & \\
\hline \multicolumn{7}{|c|}{ Neighbourhood characteristics (level 2) } \\
\hline $\mathrm{x} \%$ non-western residents & -0.155 & 0.180 & & -0.282 & 0.165 & \\
\hline x Average income level & -0.026 & 0.016 & & -0.011 & 0.015 & \\
\hline
\end{tabular}

Source: NELLS (De Graaf et al., 2010a).

$* * *$ Significant at $\mathrm{p}<0.001 ; * *$ significant at $\mathrm{p}<0.01 ; *$ significant at $\mathrm{p}<.05$.

Note: interaction effects were tested separately in models including a dummy variable for minority status and all independent variables. 